\title{
Antibiotic susceptibility of respiratory isolates among HIV-positive children in Kyrgyzstan is higher compared to those Cambodia: Is outpatients status important?
}

\author{
J. Suvada1,2, A. Liskova', V. Sladeckova1,3, J. Benca1,3, L. Gornerova', G. Mikolasova', \\ J. Kafkova', J. Vujcikova1,2, A. Kalavska1,2, P. Minarik', V. Kremery ${ }^{1,3}$, N. Kulkova', \\ M. Stalbek ${ }^{2}$
}

Original Articles

${ }^{1}$ St. Elisabeth School of Health, University HIV Clinic, Phnom Penh, Cambodia

${ }^{2}$ Regional HIV CTR Osh, Kyrgyzstan

${ }^{3}$ House of Family B1. Max Kolbe

\section{Correspondence to:}

St. Elizabeth University, MSc Program Buikwe, Nám. 1. Mája č. 1, 81000 Bratislava, Slovakia

Submitted: 26.6.2016

Revised: 10.8 .2016

Accepted: 14.9.2016

\section{Reviewers:}

G. Lezcano

University of California, San Francisco, USA

D. Kisundi

St. Charles Lwanga's Nutrition Rehabilitation Centre, Lunga Lunga, Kenya

\section{Key words:}

HIV-AIDS, HAART.

\section{Key message:}

ATB resistance mainly in S. aureus was higher in HIV children in Cambodia.

CSWHI 2016; 7(3): 35-37; DOI 10.22359/cswhi_7_3_09 @ 2016 Clinical Social Work and Health Intervention

\section{Abstract:}

Introduction: The aim of the study was to compare resistance rate against anti-retrovirals in two cohorts of children with HIV - one perinatally infected from Cambodia and the other nosocomially infected in Kyrgyzstan.

Patients and Methods: Two groups of HIV positive children were compared: Vertically infected Khmer children in Cambodia and nosocomially infected children in 3 hospitals in Kyrgyzstan.

Results: Prevalence of S. aureus and other oral cavity comensual was much lower in Kyrgyz children in comparison to Khmer children in 
Cambodia due to type of treatment with HAART (inpatients versus outpatients).

Conclusion: In inpatient setting of HIV positive children, ATB resistance is lower.

\section{Introduction}

Viral, parasitic, bacterial and fungal co-infections are very frequently present among HIV positive children and such conditions often require administration of antibiotics during their therapy (1-2). The spectrum of infections occurring in HIV positive children is wide and use of antibiotic prophylaxis can stimulate development of resistance (3-4). We aimed to evaluate the spectrum of infections among pediatric HIV patients receiving HAART (Highly Active Retroviral Therapy) and to assess resistance rates of those microorganisms in the two groups of children with HIV.

\section{Methods}

Samples obtained from $51 \mathrm{HIV}$-positive children from Osh, Bishkek, Jalal-Abad, Kara-Suu and Nookatsk, Kyrgyz Provinces who have been receiving HAART for 3 years, were included. During their previous hospital stays, children were frequently treated with ampicillin. Cultivations from samples were performed and antibiotic profiles were assessed. A group of 51 children from Kyrgyzstan was compared to 141 children from Phnom Penh and Sihanoukville. Cambodia has a 15 year follow-up program in HIV.

Tab. 1 Spectrum of microorganisms colonizing the respiratory tract in Kyrgyz versus Cambodian children with HIV on HAART

\begin{tabular}{|l|l|l|l|}
\hline Species & Kyrgyz children & Khmer children & \multicolumn{1}{|c|}{ P } \\
\hline Neisseria catarrhalis & $20.48 \%$ & $51 \%$ & $\mathrm{p}<0,01$ \\
\hline $\begin{array}{l}\text { Moraxella catarrhalis } \\
\text { AMP-R }\end{array}$ & $7.23 \%$ & $6.2 \%$ & $\mathrm{NS}$ \\
\hline $\begin{array}{l}\text { Streptococcus viridans } \\
\text { PEN-R }\end{array}$ & $20.48 \%$ & $5.1 \%$ & $\mathrm{p}<0,01$ \\
\hline $\begin{array}{l}\text { Streptococcus pneumoniae } \\
\text { PEN-R }\end{array}$ & $9.64 \%$ & $5.1 \%$ & $\mathrm{NS}$ \\
\hline MSSA & $10.84 \%$ & $10.1 \%$ & $\mathrm{NS}$ \\
\hline MRSA & $2.41 \%$ & $45.2 \%$ & $\mathrm{p}<0,001$ \\
\hline CoNS Staphylococcus spp & $8.43 \%$ & $10.1 \%$ & $\mathrm{NS}$ \\
\hline $\begin{array}{l}\text { Candida albicans } \\
\text { FLU-R }\end{array}$ & $15.66 \%$ & $10.1 \%$ & $\mathrm{NS}$ \\
\hline Others* & $4.82 \%$ & $4.0 \%$ & $\mathrm{NS}$ \\
\hline
\end{tabular}

Notes:

MSSA - methicillin-susceptible S. aureus

MRSA - methicillin-resistant S. aureus

Other:

CoNS - coagulase-negative staphylococci, *Escherichia coli (1), Proteus mirablis (1), Pseudomonas aeruginosa (1), Enterococcus faecalis (1) 


\section{Results and Discussion}

In $51 \mathrm{HIV}$ positive children we found out Neisseria catarrhalis (20.48\%), Streptococcus viridans (20.48\%) and Candida albicans $(15.66 \%)$ being the most frequent microorganisms. Interestingly, prevalence of staphylococci was not very high (18$21.69 \%$ ), and surprisingly, only 2 cases $(2.41 \%)$ of MRSA were noticed $(\mathrm{P}<0,01-$ 0,001) Tab.1.

Also, resistance rate among bacteria was really low, with clindamycin resistance acting as the most prevalent $(5.6 \%$ of bacteria isolates), followed by ampicillin and erythromycin $(4.9 \%$ and $2.8 \%$, respectively). Resistance to 5-fluorocytosine was noted in one $C$. albicans isolate, with the rest of candida isolates being fully susceptible to all antifungals tested. Co-infection with 2 or 3 microorganisms was identified in 20 patients (39.22\%).In Cambodian children, isolation of MRSA was significantly higher $(\mathrm{P}<0.01-0,001)$ (Tab. 1) (6-7).

\section{Conclusion}

Resistance rate among bacterial isolates from HIV positive Kyrgyz children is, fortunately, very low, even to ampicillin, which was often used in their previous therapy. These results are very interesting, especially when compared to our previous studies in Cambodian children after 3 years of HAART, in which resistance among gram-positives was definitely higher
(50-59\%). Thus, this group of children deserves more research to be done.

\section{References}

1. PRESTILEO T, DI LORENZE F, Corrao S: Infectious Diseases among African irregular migrants in Italy. Just an individual problem? Clin. Soc. Work 2015, 5, 45

2. SAGAT T: Sepsis in pediatrics, Lek obz, 2015, 2, 51-52

3. ESCOBIO FAVILA, ECHEVARRIA JOTA, RUBAKI SILVIA, VINICZAI VIRAG: Health assistance of displaced people along the Balkan Route, Lancet 2015, 386, Dec. 19, 2475

4. WICZMANDYOVA D, TKACOVA L, MURGOVA M: Proceedings Slov. Med. Univ: The Socio Economic aspect of Migrations, ISBN 978-80-89352-47-0, pp.62-70

5. WICZMANDYOVA D, MURGOVA A, The life of diabetics, life with diabetes, Book.Clear Michalovce ISBN 978-809711629255.2012, pp 67

6. SILHAROVA B, SUVADA J, FRANEKOVA M, NOGE A, MIKOLASOVA G: $M a-$ laria in hyperendemic region, Neuroendocrinology Letters. 34, 2013, s1 38-43

7. SUN YS, ZHAO XY, ZHANG BK, JIANG JF, LU HJ, CAO YX, WU GZ, QIAN J, SUN Y, ZENG YJ: Practices and thinking of laboratory detection in the aid to West Africa to fight against Ebola. Bratislava Medical Journal Vol.117, No.5, p.254-257, 2016. doi:10.4149/BLL_2016_049. 